\title{
ISB News September 2010
}

\section{From the President and Councillor Cegnar}

ISB Councillor, Dr Tanja Cegnar, attended the thirtysecond sessions of the United Nations Framework Convention on Climate Change (UNFCCC) Convention subsidiary bodies on behalf of ISB as a NonGovernmental Organization Participant, which took place from Monday 31 May to Friday 11 June 2010. The twelfth session of the "Ad Hoc Working Group on Further Commitments for Annex I Parties under the Kyoto Protocol" (AWG-KP) and tenth session of the "Ad Hoc Working Group on Long-term Cooperative Action under the Convention" (AWG-LCA) took place from Tuesday 1 June to Friday 11 June 2010. The venue for the meetings was the Hotel Maritim in Bonn, Germany. The ISB was one of 224 Non-Governmental Organizations represented at the Bonn Climate Change Talks (UNFCCC 2010). Dr Cegnar's full report from the Talks is available to members of the Society in the latest Biometeorology Bulletin (Volume 14, Number 1, 2010). Dr Cegnar states in that report that "As the issues under the UNFCCC are highly relevant for the ISB, I recommend that the ISB EB [Executive Board] will continue to follow the outcomes of the negotiations and related development. Especially the adaptation part of the process is closely related to the ISB field of interest, but there is also potential to contribute to the development of the mitigation measures in some sectors (e.g. sustainable farming, forestry, urban climatology)". Dr Cegnar's attendance at the meeting was fully funded by the Tromp Travel Fund.

The International Society of Biometeorology is an Admitted Non-Governmental Organization Observer to the UNFCCC, with the Society's Secretary, Prof. Mark D. Schwartz, the Designated Contact Point.

Paul J. Beggs

ISB President

Environmental Science

Department of Environment and Geography

Macquarie University

paul.beggs@mq.edu.au

\section{Tanja Cegnar}

ISB Councillor

Adviser to the Director General on Climate Change Environmental Agency of the Republic of Slovenia tanja.cegnar@gov.si

\section{Reference}

United Nations Framework Convention on Climate Change (2010) Bonn climate change talks - June 2010. http://unfccc.int/meetings/sb32/ items/5573.php. Accessed 12 July 2010 